\title{
Carcass and non-carcass characteristics of sheep fed on annatto byproduct
}

\section{Características de carcaça e constituintes não-carcaça de ovinos alimentados com subproduto de urucum}

\author{
Dorgival Morais de Lima Júnior ${ }^{1 *}$; Francisco Fernando Ramos de Carvalho²; \\ Ângela Maria Vieira Batista²; Rossana Herculano Clementino²; \\ Greicy Mitzi Bezerra Moreno'; Adriano Henrique do Nascimento Rangel ${ }^{3}$; \\ Eduardo de Almeida Silva ${ }^{4}$; Waldonys Moreira Pinheiro ${ }^{4}$
}

\begin{abstract}
Annatto byproduct is the residue from the extraction of powder dye that covers the seed pericarp; after processing, between $94 \%$ and $98 \%$ of the original product is considered a byproduct. The aim was to evaluate the influence of increasing levels of annatto byproduct on the components of sheep body weight. Thirty-two male sheep, not castrated, with initial weight of $23.17 \pm 1.45 \mathrm{~kg}$, without a defined breed, were used in randomized blocks in all four treatments $\left(0,100,200\right.$ and $300 \mathrm{~g} \mathrm{~kg}^{-1}$ of annatto byproduct in the diet dry matter). The increase to $300 \mathrm{~g} \mathrm{~kg}^{-1}$ of annatto byproduct had a negative linear effect $(\mathrm{P}<0.05)$ for hot carcass weight $(\mathrm{kg})$ and cold carcass weight $(\mathrm{kg})$. Increasing levels of annatto byproduct resulted in a linear reduction $(\mathrm{P}<0.05)$ for palette weight $(\mathrm{kg})$, leg weight $(\mathrm{kg})$, carcass compactness index $\left(\mathrm{kg} \mathrm{cm}^{-1}\right)$, liver weight $(\mathrm{kg})$ and skin weight $(\mathrm{kg})$. The inclusion of annatto byproduct up to $200 \mathrm{~g} \mathrm{~kg}^{-1}$ of dry matter in sheep diets did not affect the components of sheep body weight.
\end{abstract}

Key words: Alternative food. Carcass morphometric. Commercial cuts. Co-product.

\section{Resumo}

O subproduto do urucum é proveniente do pó-corante que recobre o pericarpo da semente; depois do processamento, entre 94 e $98 \%$ do produto original e considerado subproduto. O objetivo do estudo foi avaliar o nível crescente de inclusão do subproduto do urucum sobre os componentes do peso corporal de ovinos. Trinta e dois ovinos machos, não castrados, com peso vivo incial de $23,17 \pm 1,45 \mathrm{~kg}$, sem raça definida, foram casualizados em quatro tratamentos $\left(0,100,200\right.$ e $300 \mathrm{~g} \mathrm{~kg}^{-1}$ de subproduto do urucum na matéria seca da dieta). A adição de $300 \mathrm{~g} \mathrm{~kg}^{-1}$ subproduto do urucum provocou efeito linear negativo $(\mathrm{P}<0,05)$ sobre o peso da carcaça quente $(\mathrm{kg})$ e fria $(\mathrm{kg})$. A elevação do nível de subproduto de urucum resultou em comportamento linear negativo $(\mathrm{P}<0,05)$ para o peso da paleta $(\mathrm{kg})$, peso da perna $(\mathrm{kg})$, índice de compacidade da carcaça $\left(\mathrm{kg} \mathrm{cm}^{-1}\right)$, peso do fígado $(\mathrm{kg})$ e peso da pele $(\mathrm{kg})$. A inclusão do

\footnotetext{
${ }^{1}$ Profs., Universidade Federal de Alagoas, UFAL, Campus Arapiraca, Arapiraca, Alagoas, Brasil. E-mail: juniorzootec@yahoo. com.br; greicymitzimoreno@yahoo.com.br

2 Profs., Universidade Federal Rural de Pernambuco, UFRPE, Recife, Pernambuco, Brasil. E-mail: ffr.carvalho@dz.ufrpe.br; abatista@dz.ufrpe.br; rossanaherculano@yahoo.com.br

3 Prof., Universidade Federal do Rio Grande do Norte, UFRN, Natal, Rio Grande do Norte, Brasil. E-mail: adrianohrangel@yahoo. com.br

${ }^{4}$ Discentes do Curso de Graduação em Zootecnia, UFAL, Campus Arapiraca,Arapiraca, Alagoas, Brasil. E-mail: waldonysmoreira@ gmail.com; eddu20_hotmail.com

* Author for correspondence
} 
subproduto do urucum acima de $200 \mathrm{~g} \mathrm{~kg}^{-1}$ da matéria seca da dieta de ovinos não afeta os componentes do peso corporal de ovinos.

Palavras-chave: Alimento alternativo. Coproduto. Cortes comerciais. Morfometria da carcaça.

\section{Introduction}

The finishing of feedlot lambs does not constitute a usual practice among Brazilian sheep farmers, who traditionally adopt the extensive system of production. However, due to good marketing prospects of sheep meat, it is necessary to intensify the lamb termination process to reduce the production cycle and improve carcass quality (COSTA et al., 2011).

Generally, variable costs associated with the feeding of animals in feedlots account for a significant share of this system's total spending. Associated with this, there is a lack of vocation in the Northeast region for the production of ingredients traditionally used in animal feed, such as corn and soybeans.

In this context, the use of agro-industrial byproducts in feeding sheep has become increasingly common as an alternative to reduce production costs per kilogram of meat, and it may alternatively be economically viable and environmentally friendly for intensive production systems of sheep meat (AWAWDEH, 2011; AZEVÊDO et al., 2011).

A byproduct that is attracting interest is the result from the processing of a tropical shrub known as annatto (Bixa orellana L.) (PEREIRA et al., 2008; SILVA et al., 2005). According to De Rosso and Mercadante (2009), Brazil is the greatest producer and exporter of annatto seeds and extracts, which are used as a colorant in the food, pharmaceutical and cosmetic industries.

Annatto byproduct $(\mathrm{AB})$ is the residue from the extraction of powder dye that covers the seed pericarp. After processing, between $94 \%$ and $98 \%$ of the original product is considered a byproduct (BRAZ et al., 2007; PRESTON; RICKARD, 1980).
Clementino (2008) studied the inclusion of $0,200,400,600$ and $800 \mathrm{~g} \mathrm{~kg}^{-1}$ of $\mathrm{AB}$ in the dry matter (DM) of diets containing Tifton 85 hay for sheep and noted that the intake of DM expressed in $\mathrm{g} \mathrm{day}^{-1}, \%$ live weight (LW) and $\mathrm{g} \mathrm{kg}^{-0.75}$ increased linearly with the addition of $\mathrm{AB}$ to diets. The same behavior was observed for the consumption of organic matter $\left(\mathrm{g} \mathrm{day}^{-1}, \% \mathrm{LW}\right.$ and $\left.\mathrm{g} \mathrm{kg}^{-0.75}\right)$, crude protein $\left(\mathrm{g}\right.$ day $^{-1}, \% \mathrm{LW}$ and $\left.\mathrm{g} \mathrm{kg}^{-0.75}\right)$ and nonfibrous carbohydrates ( $\mathrm{g} \mathrm{day}^{-1}, \% \mathrm{LW}$ and $\mathrm{g} \mathrm{kg}^{-0.75}$ ). Linear increases in digestibility coefficients (\%) of $\mathrm{DM}$, crude protein and total carbohydrates were also observed with the inclusion of $\mathrm{AB}$.

The nutritional component of animal production systems is the main factor involved in animal growth and development, which thus influences the yield and weight of sheep body parts (GONZAGA NETO et al., 2006; MEDEIROS et al., 2009; PEREIRA et al., 2010).

Considering the above, the aim was to evaluate the influence of increasing levels of annatto (Bixa orellana L.) byproduct on the components of sheep body weight.

\section{Materials and Methods}

The experiment was conducted at the Animal Science Department of the Federal Rural University of Pernambuco (UFRPE), located in Recife and situated at geographical coordinates $8^{\circ}$ $04^{\prime} 03^{\prime}$ ' S and $34^{\circ} 55^{\prime} 00^{\prime \prime} \mathrm{W}$, with an altitude of 4 $\mathrm{m}$. The climate is classified according to Köppen as type Ams', which is characterized by being hot and humid, with an average annual temperature of $25.2{ }^{\circ} \mathrm{C}$.

Thirty-two intact male lambs, without a defined breed, with initial weight of $23.17 \pm 1.45 \mathrm{~kg}$ and an average age of 8 months were used. The animals 
were blocked, according to weight, into four treatments, totaling eight replications.

Upon arrival, the animals were treated against endoparasites and ectoparasites $\left(\right.$ TRIMIX $^{\circledR}$ ) and vaccinated against clostridial diseases (SINTOXAN $^{\circledR}$ 9TH). The experimental period lasted 78 days, being 20 days of adaptation and 58 days of data collection.

Throughout the experimental period, the animals were kept in individual stalls with $1.0 \mathrm{~m} \times 2.8 \mathrm{~m}$ dimensions supplied with feeders and drinkers, with water at will. In this period, the supply of food, leftovers and animals were weighed to quantify the consumption of food and animal performance, respectively.

The treatments consisted of four levels of inclusion of $\mathrm{AB}\left(0,100,200\right.$ and $\left.300 \mathrm{~g} \mathrm{~kg}^{-1}\right)$ in diet DM (Table 1). The control diet $\left(0 \mathrm{~g} \mathrm{~kg}^{-1} \mathrm{AB}\right)$ was formulated to meet male sheep requirements with a $25 \mathrm{~kg}$ average weight for maintenance and gain of $150 \mathrm{~g} \mathrm{day}^{-1}$ (NATIONAL RESEARCH COUNCIL, 2007). The chemical composition of the ingredients used in experimental diets and the percentage composition of the diets are shown in Tables 1 and 2.

Table 1. Chemical composition and percentage (\% dry matter) of the experimental diets.

\begin{tabular}{lcccc}
\hline \multirow{1}{*}{ Ingredients } & \multicolumn{4}{c}{ Annatto byproduct levels $\left(\mathrm{g} \mathrm{kg}^{-1}\right)$} \\
\cline { 2 - 5 } & 0 & 100 & 200 & 300 \\
\hline Tifton 85, hay & 55 & 55 & 55 & 55 \\
Corn, grain & 30 & 22.2 & 12.8 & 4.1 \\
Soy, bran & 13 & 10.8 & 10.2 & 8.9 \\
Annatto, byproduct & 0 & 10 & 20 & 30 \\
Urea & 1 & 1 & 1 & 1 \\
Mineral salt & 1 & 1 & 1 & 1 \\
Total & 100 & 100 & 100 \\
\hline & & Chemical composition & 100 \\
DM $\left(\mathrm{g} \mathrm{kg}^{-1} \mathrm{natural}\right.$ matter & 915.9 & 911.1 & 906.2 & 901.5 \\
$\mathrm{OM}\left(\mathrm{g} \mathrm{kg}^{-1} \mathrm{DM}\right)$ & 934.9 & 934.9 & 930.8 & 930.2 \\
$\mathrm{CP}\left(\mathrm{g} \mathrm{kg}^{-1} \mathrm{DM}\right)$ & 155.5 & 153.5 & 157.5 & 157.5 \\
$\mathrm{EE}\left(\mathrm{g} \mathrm{kg}^{-1} \mathrm{DM}\right)$ & 46.6 & 45.9 & 43.7 & 42.1 \\
$\mathrm{NDF}\left(\mathrm{g} \mathrm{kg}^{-1} \mathrm{DM}\right)$ & 484.7 & 514.7 & 544.6 & 574.6 \\
$\mathrm{ADF}\left(\mathrm{g} \mathrm{kg}^{-1} \mathrm{DM}\right)$ & 249.9 & 266.0 & 282.0 & 298.1 \\
$\mathrm{TC}\left(\mathrm{g} \mathrm{kg}^{-1} \mathrm{DM}\right)$ & 734.9 & 735.6 & 729.7 & 730.6 \\
$\mathrm{NFC}\left(\mathrm{g} \mathrm{kg}^{-1} \mathrm{DM}\right)$ & 250.2 & 220.9 & 185.06 & 155.97 \\
$\mathrm{TDN}\left(\mathrm{g} \mathrm{kg}^{-1}\right)$ & 729.5 & 727.3 & 703.0 & 710.2 \\
$\mathrm{ME}\left(\mathrm{Mcal} \mathrm{kg} \mathrm{DM}^{-1}\right)^{2}$ & 2.34 & 2.37 & 2.13 & 2.17 \\
\hline
\end{tabular}

${ }^{1}$ Commercial product; ${ }^{2}$ obtained from TDN (WEISS, 1999); $1 \mathrm{~kg}$ of TDN is equivalent to 4409 Mcal of digestive energy (DE); metabolizable energy $(\mathrm{ME})=81.7 \% \mathrm{DE}$.

$\mathrm{DM}=$ dry matter; $\mathrm{OM}=$ organic matter; $\mathrm{CP}=$ crude protein; $\mathrm{EE}=$ ether extract; $\mathrm{NDF}=$ neutral detergent fiber; $\mathrm{ADF}=$ acid detergent fiber; $\mathrm{TC}=$ total carbohydrates; $\mathrm{NFC}=$ non-fiber carbohydrates; TDN $=$ total digestible nutrients. 
Table 2. Chemical composition of the ingredients used in the diets.

\begin{tabular}{lcccccccccc}
\hline & \multicolumn{10}{c}{ Analytical fractions $\left(\mathrm{g} \mathrm{kg}^{-1}\right)$} \\
\hline Ingredients & DM & OM & MM & EE & CP & NDF & ADF & TC & NFC & TDN \\
Tifton 85, hay & 925.0 & 925.6 & 66.0 & 22.0 & 75.1 & 762.4 & 422.2 & 842.3 & 79.9 & 510.0 \\
Annatto, byproduct & 858.0 & 936.8 & 63.2 & 81.2 & 145.5 & 451.0 & 201.8 & 710.1 & 259.1 & 646.0 \\
Soy, bran & 893.2 & 929.9 & 68.1 & 14.1 & 487.1 & 155.2 & 41.3 & 430.7 & 275.5 & 820.0 \\
Corn, grain & 904.6 & 963.9 & 36.1 & 109.0 & 83.7 & 151.0 & 41.3 & 771.2 & 620.2 & 850.2 \\
Urea & 990.0 & - & - & - & 2810.0 & - & - & - & - & - \\
Mineral mixture & 990.0 & - & 999.9 & - & - & - & - & - & - & - \\
\hline
\end{tabular}

$\mathrm{DM}=$ dry matter; $\mathrm{OM}=$ organic matter; $\mathrm{MM}=$ mineral matter; $\mathrm{EE}=$ ether extract; $\mathrm{CP}=$ crude protein; $\mathrm{NDF}=$ neutral detergent fiber; $\mathrm{ADF}=$ acid detergent fiber; $\mathrm{TC}=$ total carbohydrates; $\mathrm{NFC}=$ non-fiber carbohydrates; $\mathrm{TDN}=$ total digestible nutrients.

The analyses of DM, mineral matter (MM), crude protein (CP) and ether extract (EE) followed the methodologies described by Silva and Queiroz (2002). To determine neutral detergent fiber (NDF) and acid detergent fiber (ADF), the methodologies described by Van Soest et al. (1991) were used, with modification in relation to bags (polypropylene bags were used; non-woven fabric, weight $100 \mathrm{~g}$ $\mathrm{m}^{-2}$ ) and autoclave.

For the estimation of total carbohydrates (TC) and non-fiber carbohydrates (NFC), respectively, the following equations were used as proposed by Sniffen et al. (1992): TC $=100-(\% \mathrm{CP}+\% \mathrm{EE}+$ $\% \mathrm{MM}) ; \mathrm{NFC}=100 \%-(\% \mathrm{CP}+\% \mathrm{NDF}+\% \mathrm{EE}+$ $\% \mathrm{MM}$ ). The total digestible nutrients intake (TDNI) was calculated as described by Weiss (1999): TDNI $=\mathrm{CPD}+\mathrm{EED} \times 2.25+\mathrm{NFCD}+\mathrm{NDFD}$, where CPD $=(\mathrm{CP}$ ingested $-\mathrm{CP}$ feces $), \mathrm{EED}=($ ingested $\mathrm{EE}-$ EE feces $), \mathrm{NFCD}=($ ingested NFC - NFC feces $)$ and NDFD $=($ NDF ingested - NDF feces $)$, and total digestible nutrient content (TDN) was calculated by: $(\% \mathrm{TDN}=$ consumption/DM consumption $\times 100)$.

After the confinement period, animals were randomized in a slaughter order and submitted to solid fasting for $16 \mathrm{~h}$. At slaughter, the animals were weighed to obtain slaughter body weight (SBW), desensitized by concussion through non-penetrative percussion, suspended by the hind limbs through ropes and bled by a cut of the carotid arteries and jugular veins (BRASIL, 2000).

Still suspended, the animals were manually scraped using common knives according to the methodology of Cezar and Sousa (2007). The head was separated by section of the cervical vertebrae at the atlanto-occipital joint, and the feet were obtained by a cut of the front legs in the carpal-metacarpal joints and of the hind limbs by a cut of the tarsusmetatarsal joints.

The internal components of the pelvic, abdominal and thoracic cavities were extracted and their weights were recorded. The gastrointestinal tract content was quantified by the difference between the weights of the full and empty gastrointestinal tract. The SBW subtracted from the gastrointestinal content matched the empty body weight (EBW) (CEZAR; SOUZA, 2007; SILVA SOBRINHO, 2001).

The animals bled, decapitated, skinned, gutted, amputated and with kidneys and perirenal fat constituted the hot carcass. With the hot carcass weight (HCW) obtained, they were conducted to the cold room, with an average temperature of 4 ${ }^{\circ} \mathrm{C}$, where they remained for $24 \mathrm{~h}$ suspended from single hooks by the tendon of the gastrocnemius muscle. The carcass weight after $24 \mathrm{~h}$ in cooling corresponded to the cold carcass weight (CCW). 
Cooling loss (CL) (\%) was quantified using the formula $\mathrm{CL}(\%)=(\mathrm{HCW}-\mathrm{CCW} / \mathrm{HCW}) \times 100$ (SILVA SOBRINHO, 2001).

Still suspended, the following morphometric measurements were obtained from the cold carcasses: carcass internal length, carcass external length, leg length, thoracic perimeter, rump perimeter, thorax depth, thorax width and rump width according to the methodology of Cezar and Sousa (2007).

The carcass compactness index (CCI) and leg compactness index (LCI) were obtained by the following formulas: $\mathrm{CCI}\left(\mathrm{kg} \mathrm{cm}^{-1}\right)=\mathrm{CCW} /$ carcass internal length, and LCI = rump width/leg length.

After the measurements on cold carcasses, the kidneys and perirenal fat were removed, which were subtracted from $\mathrm{HCW}$ and $\mathrm{CCW}$ for calculation of hot carcass, cold carcass and biological yields following the formulas: HCY $(\%)=(\mathrm{HCW} / \mathrm{SBW})$ $\times 100 ; \mathrm{CCY}(\%)=(\mathrm{CCW} / \mathrm{SBW}) \times 100 ;$ and $\mathrm{BY}$ $(\%)=(\mathrm{HCW} / \mathrm{EBW}) \times 100$, respectively $(\mathrm{SILVA}$ SOBRINHO, 2001).

After removal of the tail, each carcass was sagittally divided and the left half sectioned into six anatomical regions that made the following cuts: neck, palette, rib, loin, leg and sawcut, according to a methodology from Cezar and Sousa (2007). The individual weight of each cut, composed of the cuts made in the left half carcass, was recorded for calculation of proportion related to the sum of halfreconstituted carcasses, thus obtaining the carcass cut yields.

In the left half carcass, there was a crosssection between the 12th and 13th ribs, exposing the cross-section of the longissimus dorsi muscle, whose area was dashed with a permanent marker, with a medium point of $2.0 \mathrm{~mm}$, on a transparent plastic film to obtain the loin eye area (LEA). Thus, by means of a graduated $30 \mathrm{~cm}$ ruler, the maximum width (A) and the maximum depth (B) were obtained to be used in the formula: LEA = $(\mathrm{A} / 2 \times \mathrm{B} / 2) \pi$, according to Silva Sobrinho (2001), and thus its area was determined. The thickness of loin subcutaneous fat was measured with a caliper, obtained at three-quarters of the distance from the medial side of the longissimus dorsi muscle, the midline.

Non-carcass components: organs (heart, lungs, spleen, liver, kidneys, pancreas, diaphragm, tongue), viscera (rumen, reticulum, omasum, abomasum, small intestine and large intestine) and slaughter byproducts (blood, skin, head, paws and internal fatty deposits: omentum, mesentery, pelvic +kidney and fat linked to intestines) were considered, as proposed by Silva Sobrinho (2001).

The data were submitted to analysis of variance, regression analysis and mean test. For the regression, models were chosen based on the significance of the coefficient of determination. The $\mathrm{P}$-values were significant at $0.05 \%$ probability and considered a tendency at $0.10 \%$ probability. To compare the means, Dunnett's test was used, adopting $0.05 \%$ as a critical level of probability for error type I. Statistical analyses were performed using SAEG (Statistical Analysis System and Genetic) software.

\section{Results and Discussion}

HCW and CCW decreased linearly $(\mathrm{P}<0.05)$ with the inclusion of $\mathrm{AB}$ in the diet (Table 3$)$. 
Table 3. Weights and carcass yields from sheep fed with increasing levels of annatto byproduct.

\begin{tabular}{lcccccccc}
\hline \multirow{2}{*}{\multicolumn{1}{c}{ Variables }} & \multicolumn{9}{c}{ Annatto byproduct levels $\left(\mathrm{g} \mathrm{kg}^{-1}\right)$} & \multicolumn{3}{c}{$\mathrm{P}$} \\
\cline { 2 - 9 } & 0 & 100 & 200 & 300 & Mean $\pm \mathrm{SE}$ & $\mathrm{L}$ & $\mathrm{Q}$ & $\mathrm{CV}(\%)$ \\
\hline Initial body weight $(\mathrm{kg})$ & 23.16 & 23.49 & 22.95 & 23.09 & $23.17 \pm 1.45$ & $\mathrm{~ns}$ & $\mathrm{~ns}$ & 2.78 \\
Body weight at slaughter $(\mathrm{kg})$ & 34.38 & 34.56 & 32.52 & 32.85 & $33.58 \pm 2.61$ & $\mathrm{~ns}$ & $\mathrm{~ns}$ & 7.08 \\
Gastrointestinal tract content $(\mathrm{kg})$ & 5.55 & 5.76 & 5.44 & 5.40 & $5.54 \pm 0.80$ & $\mathrm{~ns}$ & $\mathrm{~ns}$ & 14.70 \\
Empty body weight (kg) & 28.83 & 28.79 & 27.08 & 27.45 & $28.04 \pm 2.19$ & $\mathrm{~ns}$ & $\mathrm{~ns}$ & 6.93 \\
Hot carcass weight (kg) & 16.03 & 16.04 & 15.06 & 14.92 & $15.51 \pm 1.39$ & $0.03^{1}$ & $\mathrm{~ns}$ & 7.83 \\
Cold carcass weight (kg) & 15.20 & 15.20 & 14.29 & 14.10 & $14.69 \pm 1.28$ & $0.02^{2}$ & $\mathrm{~ns}$ & 7.70 \\
Hot carcass yield (\%) & 46.64 & 46.37 & 46.30 & 45.41 & $46.18 \pm 1.40$ & $\mathrm{~ns}$ & $\mathrm{~ns}$ & 2.85 \\
Cold carcass yield (\%) & 44.21 & 43.94 & 43.95 & 42.91 & $43.75 \pm 1.42$ & $\mathrm{~ns}$ & $\mathrm{~ns}$ & 3.14 \\
Biological yield (\%) & 57.03 & 57.21 & 56.92 & 55.90 & $56.78 \pm 1.68$ & $\mathrm{~ns}$ & $\mathrm{~ns}$ & 3.01 \\
Cooling loss (\%) & 5.20 & 5.21 & 5.05 & 5.51 & $5.24 \pm 1.39$ & $\mathrm{~ns}$ & $\mathrm{~ns}$ & 27.85 \\
\hline
\end{tabular}

$\mathrm{SE}=$ standard error; ${ }^{\mathrm{ns}}$ not significant. Equations: ${ }^{1} \hat{\mathrm{Y}}=16.16-0.04 \mathrm{X}^{*}, \mathrm{R}^{2}=0.84 ;{ }^{2} \hat{\mathrm{Y}}=15.33-0.04 \mathrm{X}^{*}, \mathrm{R}^{2}=0.86$.

The increase of $\mathrm{AB}$ level decreased the diet energy density (Table 1), negatively influencing the $\mathrm{HCW}(\mathrm{kg})$ and $\mathrm{CCW}(\mathrm{kg})$ of animals. Diet energy density influences the development of animals, influencing, in turn, the weight and carcass yield (GONZAGA NETO et al., 2006; MEDEIROS et al., 2009; PEREIRA et al., 2010). It is noteworthy that, despite the negative linear behavior for carcass weight, Dunnett's test $(\mathrm{P}<0.05)$ did not identify differences between the control treatment and other treatments with the inclusion of $\mathrm{AB}$.

Carcass yield is influenced by a variety of factors, among which gastrointestinal tract content (GTC) stands out. In the present study, GTC was equivalent to $16.50 \%$ of the body weight of the animal at slaughter. The forage-to-concentrate ratio of $55: 45$ and the type of voluminous content certainly contributed to the high levels of GTC ( $\mathrm{kg}$ and $\%)$.

HCY and CCY showed averages of $46.18 \%$ and $43.75 \%$, respectively. Although they did not differ among treatments $(\mathrm{P}>0.05), \mathrm{HCW}$ and $\mathrm{CCW}$ tended $(\mathrm{P}=0.083$ and $\mathrm{P}=0.084)$ to a negative linear behavior. CL were higher than $5 \%$ in all other treatments and did not differ $(\mathrm{P}>0.05)$ among them.

CL did not suffer the influence of annatto inclusion levels $(\mathrm{P}>0.05)$. However, they were high (5.24\%). CL of $5.00 \%$ were reported by Gonzaga Neto et al. (2006) for Morada Nova sheep. These losses depend on the amount of fat cover, which in native or non-specialized genotypes is low due to different partition of adipose tissue in the body of this group of animals (MEDEIROS et al., 2011; MIRKENA et al., 2010).

Palette weight $(\mathrm{kg})$ and leg weight $(\mathrm{kg})$ decreased linearly $(\mathrm{P}<0.05)$ with the addition of $\mathrm{AB}$ to diets (Table 4). Due to a low line coefficient, Dunnett's test was also used to compare the means of the control $\left(0 \mathrm{~g} \mathrm{~kg}^{-1} \mathrm{AB}\right)$ with the other treatments. The inclusion of $300 \mathrm{~g} \mathrm{~kg}^{-1} \mathrm{AB}$ reduced the weight of the half cold carcass $(\mathrm{kg})$, palette $(\mathrm{kg})$ and leg $(\mathrm{kg})$, when compared to the control treatment. 
Table 4. Regional composition of carcasses of sheep fed with increasing levels of annatto byproduct.

\begin{tabular}{|c|c|c|c|c|c|c|c|c|}
\hline \multirow{2}{*}{ Variables } & \multicolumn{5}{|c|}{ Annatto byproduct levels $\left(\mathrm{g} \mathrm{kg}^{-1}\right)$} & \multicolumn{3}{|c|}{$\mathrm{P}$} \\
\hline & 0 & 100 & 200 & 300 & Mean \pm SE & $\mathrm{L}$ & Q & CV $(\%)$ \\
\hline \multicolumn{9}{|l|}{ Absolute weight } \\
\hline Palette (kg) & 1.43 & 1.41 & 1.33 & $1.31^{\#}$ & $1.37 \pm 0.12$ & $0.01^{1}$ & ns & 7.61 \\
\hline Neck (kg) & 0.83 & 0.86 & 0.77 & 0.78 & $0.81 \pm 0.09$ & ns & ns & 12.09 \\
\hline Rib (kg) & 1.27 & 1.30 & 1.18 & 1.19 & $1.23 \pm 0.15$ & ns & ns & 12.68 \\
\hline Sawcut $(\mathrm{kg})$ & 0.84 & 0.86 & 0.83 & 0.77 & $0.83 \pm 0.13$ & ns & ns & 15.22 \\
\hline Loin $(\mathrm{kg})$ & 0.60 & 0.59 & 0.55 & 0.55 & $0.57 \pm 0.07$ & ns & ns & 12.24 \\
\hline Leg $(\mathrm{kg})$ & 2.58 & 2.53 & 2.49 & $2.11^{\#}$ & $2.43 \pm 0.41$ & $0.02^{3}$ & ns & 15.80 \\
\hline \multicolumn{9}{|l|}{ Yields } \\
\hline Palette (\%) & 18.95 & 18.74 & 18.58 & 19.65 & $18.98 \pm 1.31$ & ns & ns & 7.09 \\
\hline Neck (\%) & 10.98 & 11.42 & 10.76 & 11.66 & $11.21 \pm 1.10$ & $\mathrm{~ns}$ & ns & 10.21 \\
\hline $\operatorname{Rib}(\%)$ & 16.78 & 17.17 & 16.45 & 17.79 & $17.05 \pm 1.36$ & $\mathrm{~ns}$ & ns & 8.08 \\
\hline Sawcut (\%) & 11.09 & 11.32 & 11.70 & 11.70 & $11.45 \pm 1.85$ & ns & ns & 16.99 \\
\hline Loin (\%) & 7.98 & 7.77 & 7.73 & 8.31 & $7.95 \pm 0.80$ & ns & ns & 9.83 \\
\hline Leg $(\%)$ & 34.20 & 33.59 & 34.77 & 30.88 & $33.36 \pm 4.54$ & ns & ns & 13.69 \\
\hline
\end{tabular}

The weights of the loin $(0.57 \mathrm{~kg})$, sawcut $(0.83$ $\mathrm{kg})$ and neck $(0.81 \mathrm{~kg})$ were not affected $(\mathrm{P}>0.05)$ by the inclusion of $\mathrm{AB}$. The cut yields were not affected $(\mathrm{P}>0.05)$ by the inclusion of the byproduct.

The palette weight $(\mathrm{kg})$ and leg weight $(\mathrm{kg})$ decreased linearly $(\mathrm{P}<0.05)$ with the addition of $\mathrm{AB}$ to diets (Table 4). Members have an early growth and concentrate the largest muscle masses of the animal body, so the effect of the nutritional plan can be seen in carcass ends more markedly than in other anatomical regions (GERRARD; GRANT, 2006).

Probably, the highest weights of the palette and leg, which together accounted for $52.34 \%$ of the carcass, also contribute to explaining the observed differences between $\mathrm{HCW}$ and $\mathrm{CCW}$ among treatments (Table 3).
Increasing levels of $\mathrm{AB}$ afforded a linear decrease $(\mathrm{P}<0.05)$ in leg length $(\mathrm{cm})$ and CCI $(\mathrm{kg}$ $\mathrm{cm}^{-1}$ ) (Table 5).

Measurements of length, width, depth and perimeter obtained from the carcasses were not influenced $(\mathrm{P}>0.05)$ by the inclusion of $\mathrm{AB}$. Morphometric measurements, except for leg length, were not affected by the levels of inclusion of $\mathrm{AB}$. The $1.10 \mathrm{~kg}$ difference in CCW among treatments may explain the lack of difference between most carcass measurements.

The negative linear behavior of CCI can be explained by the reduction, also linear $(\mathrm{P}<0.05)$, of CCW. Oliveira et al. (1998) reported a 0.98 correlation coefficient $(\mathrm{P}<0.01)$ between carcass compactness and $\mathrm{CCW}$ of sheep of different genotypes. 
Table 5. Morphometric measurements, indices, fat thickness and loin eye area of carcasses of sheep fed with increasing levels of annatto byproduct.

\begin{tabular}{lcccccccc}
\hline \multirow{2}{*}{ Variables } & \multicolumn{9}{c}{ Annatto byproduct levels $\left(\mathrm{g} \mathrm{kg}^{-1}\right)$} & \multicolumn{3}{c}{$\mathrm{P}$} \\
\cline { 2 - 8 } & 0 & 100 & 200 & 300 & Mean $\pm \mathrm{SE}$ & $\mathrm{L}$ & $\mathrm{Q}$ & $\mathrm{CV}(\%)$ \\
\hline External length $(\mathrm{cm})$ & 58.31 & 58.36 & 58.65 & 57.35 & $58.17 \pm 1.78$ & $\mathrm{~ns}$ & $\mathrm{~ns}$ & 3.19 \\
Internal length $(\mathrm{cm})$ & 61.12 & 62.31 & 61.44 & 61.25 & $61.53 \pm 2.04$ & $\mathrm{~ns}$ & $\mathrm{~ns}$ & 3.29 \\
Thorax width $(\mathrm{cm})$ & 23.18 & 21.96 & 21.91 & 22.65 & $22.43 \pm 2.37$ & $\mathrm{~ns}$ & $\mathrm{~ns}$ & 11.02 \\
Rump perimeter $(\mathrm{cm})$ & 60.71 & 61.12 & 60.31 & 60.20 & $60.59 \pm 1.94$ & $\mathrm{~ns}$ & $\mathrm{~ns}$ & 3.02 \\
Rump width (cm) & 17.18 & 15.96 & 16.87 & 17.37 & $16.85 \pm 1.84$ & $\mathrm{~ns}$ & $\mathrm{~ns}$ & 11.09 \\
Leg length $(\mathrm{cm})$ & 41.58 & 39.54 & 39.37 & 39.35 & $39.96 \pm 2.15$ & $0.043^{1}$ & $\mathrm{~ns}$ & 5.12 \\
Leg perimeter (cm) & 31.47 & 31.64 & 31.22 & 29.86 & $31.05 \pm 1.98$ & $\mathrm{~ns}$ & $\mathrm{~ns}$ & 6.54 \\
Thorax depth (cm) & 27.65 & 27.40 & 28.67 & 27.60 & $27.83 \pm 1.33$ & $\mathrm{~ns}$ & $\mathrm{~ns}$ & 4.63 \\
Thoracic perimeter (cm) & 69.65 & 68.56 & 68.55 & 68.69 & $68.86 \pm 2.75$ & $\mathrm{~ns}$ & $\mathrm{~ns}$ & 4.21 \\
Loin eye area (cm $\left.{ }^{2}\right)$ & 13.10 & 12.53 & 11.69 & 12.41 & $12.43 \pm 2.24$ & $\mathrm{~ns}$ & $\mathrm{~ns}$ & 18.42 \\
Fat thickness (mm) & 1.59 & 1.63 & 1.99 & 1.77 & $1.75 \pm 0.67$ & $\mathrm{~ns}$ & $\mathrm{~ns}$ & 41.66 \\
Carcass compactness & 0.25 & 0.25 & 0.23 & 0.24 & $0.24 \pm 0.02$ & $0.031^{2}$ & $\mathrm{~ns}$ & 7.82 \\
index (kg cm $\left.{ }^{-1}\right)$ & & & & & & \\
Leg compactness index & 0.41 & 0.40 & 0.43 & 0.44 & $0.42 \pm 0.05$ & $\mathrm{~ns}$ & $\mathrm{~ns}$ & 12.72 \\
\hline
\end{tabular}

$\mathrm{SE}=$ standard error; ${ }^{\text {ns }}$ not significant. Equations: ${ }^{1} \hat{\mathrm{Y}}=40.99-0.07 \mathrm{X}, \mathrm{R}^{2}=0.67 ;{ }^{2} \hat{\mathrm{Y}}=0.256-0.001 \mathrm{X}, \mathrm{R}^{2}=0.92$.

According to Junkuszew and Ringdorfer (2005), LEA is an excellent estimator of carcass muscularity, showing a 0.69 correlation with this parameter. In the present study, LEA averaged 12.4 $\mathrm{cm}^{2}$, not influenced $(\mathrm{P}>0.05)$ by the addition of AB. Values obtained in this study were similar to those reported by Lombardi et al. (2010) and by Moreno et al. (2010), who worked with slaughtered sheep averaging $30 \mathrm{~kg}$ body weight.

The inclusion of the $\mathrm{AB}$ in the diet positively influenced $(\mathrm{P}<0.05)$ liver weight (Table 6). It is common that the weight of liver and other primary metabolism organs, such as heart and lungs, monitors the power levels of the diet
(FONTENELE et al., 2010; MEDEIROS et al., 2008). In the present study, this behavior was not observed.

One hypothesis for enlarged liver is a probable toxic effect of annatto. Hepatotoxicity of annatto extract was discarded by Bautista et al. (2004) and Garcia et al. (2012); however, Paula et al. (2009) reported that the addition of aqueous extract of annatto seed to rat diet caused liver hypertrophy. Thus, it can be inferred that the excess of atypical carotenoids present in diets with increasing levels of annatto contributed to the increased liver weight, since this organ is where lipids are metabolized. 
Table 6. Weight of non-carcass components of sheep fed with increasing levels of annatto byproduct.

\begin{tabular}{|c|c|c|c|c|c|c|c|c|}
\hline \multirow[b]{2}{*}{ Variables } & \multicolumn{5}{|c|}{ Annatto byproduct levels $\left(\mathrm{g} \mathrm{kg}^{-1}\right)$} & \multicolumn{3}{|c|}{$\mathrm{P}$} \\
\hline & 0 & 100 & 200 & 300 & Mean \pm SE & $\mathrm{L}$ & $\mathrm{Q}$ & $\mathrm{CV}(\%)$ \\
\hline \multicolumn{9}{|l|}{ Organs } \\
\hline Tongue $(\mathrm{kg})$ & 0.09 & 0.08 & 0.09 & 0.08 & $0.09 \pm 0.02$ & ns & ns & 21.01 \\
\hline Lungs (kg) & 0.37 & 0.34 & 0.32 & 0.36 & $0.34 \pm 0.06$ & ns & ns & 17.08 \\
\hline Heart (kg) & 0.14 & 0.15 & 0.13 & 0.14 & $0.14 \pm 0.02$ & $\mathrm{~ns}$ & ns & 13.91 \\
\hline Liver $(\mathrm{kg})$ & 0.57 & 0.61 & 0.66 & 0.65 & $0.63 \pm 0.08$ & $0.04^{1}$ & ns & 13.52 \\
\hline Spleen $(\mathrm{kg})$ & 0.07 & 0.07 & 0.06 & 0.06 & $0.06 \pm 0.05$ & ns & ns & 18.82 \\
\hline Pancreas (kg) & 0.07 & 0.06 & 0.06 & 0.06 & $0.06 \pm 0.01$ & ns & ns & 19.66 \\
\hline Kidneys (kg) & 0.01 & 0.01 & 0.01 & 0.01 & $0.01 \pm 0.01$ & $\mathrm{~ns}$ & ns & 11.68 \\
\hline \multicolumn{9}{|l|}{ Viscera } \\
\hline Rumen (kg) & 0.66 & 0.68 & 0.62 & 0.66 & $0.66 \pm 0.08$ & ns & ns & 12.88 \\
\hline Reticulum (kg) & 0.13 & 0.11 & 0.11 & 0.13 & $0.12 \pm 0.02$ & ns & ns & 16.09 \\
\hline Omasum (kg) & 0.08 & 0.09 & 0.08 & 0.09 & $0.08 \pm 0.02$ & ns & ns & 21.26 \\
\hline Abomasum (kg) & 0.15 & 0.14 & 0.13 & 0.15 & $0.14 \pm 0.02$ & $\mathrm{~ns}$ & $\mathrm{~ns}$ & 16.42 \\
\hline Small intestine $(\mathrm{kg})$ & 0.71 & 0.70 & 0.68 & 0.71 & $0.70 \pm 0.10$ & ns & ns & 16.12 \\
\hline Large intestine $(\mathrm{kg})$ & 0.39 & 0.39 & 0.34 & 0.37 & $0.37 \pm 0.06$ & $\mathrm{~ns}$ & $\mathrm{~ns}$ & 15.46 \\
\hline \multicolumn{9}{|l|}{ Slaughter byproducts } \\
\hline Blood (kg) & 1.36 & 1.35 & 1.33 & 1.35 & $1.35 \pm 0.19$ & ns & ns & 14.47 \\
\hline Skin $(k g)$ & 2.63 & 2.60 & 2.42 & 2.32 & $2.49 \pm 0.32$ & $0.02^{2}$ & $\mathrm{~ns}$ & 11.03 \\
\hline Paws (kg) & 0.81 & 0.83 & 0.78 & 0.81 & $0.81 \pm 0.07$ & ns & ns & 8.37 \\
\hline Head (kg) & 1.86 & 1.87 & 1.77 & 1.85 & $1.84 \pm 0.12$ & ns & ns & 6.61 \\
\hline Internal fat $(\mathrm{kg})^{\mathrm{a}}$ & 1.25 & 1.20 & 1.14 & 1.29 & $1.22 \pm 0.31$ & ns & ns & 25.61 \\
\hline
\end{tabular}

$\mathrm{SE}=$ standard error; ${ }^{\text {ns }}$ not significant; ${ }^{\text {a }}$ Fat attached to omentum, mesentery, kidneys and intestines. Equations: ${ }^{1} \hat{\mathrm{Y}}=0.583+$ $0.003 X, R^{2}=0.80 ;{ }^{2} \hat{Y}=2.661-0.011 X ; R^{2}=0.94$.

The skin is the largest non-carcass component of commercial value, amounting to $20 \%$ of the total commercial value of the animal. Skin weight linearly decreased $(\mathrm{P}<0.05)$ in sheep fed diets including AB. Based on the results of Garcia et al. (2014), who observed positive heterogonic growth for skin, it can be inferred that the tendency to reduction of EBW ( $p=0.06)$ on inclusion of $A B$ explains the behavior observed for skin weight.

As for the fatty deposits, there was no effect $(\mathrm{P}>0.05)$ on the internal deposition of different fats with $\mathrm{AB}$ inclusion. The relationships of total fat deposits to body weight at slaughter (3.63\%) and EBW (4.34\%) were, in absolute terms, very high. This fact relates that native breeds of sheep prioritize internal fat deposits (MEDEIROS et al., 2011; MIRKENA et al., 2010).

The inclusion of $\mathrm{AB}$ up to $200 \mathrm{~g} \mathrm{~kg}^{-1}$ of DM of sheep diets did not affect the components of sheep body weight. Thus, the inclusion of this byproduct in the diet can be made, but it is dependent on the cost of the alternative food.

\section{Acknowledgements}

To Fundação de Amparo a Pesquisa Científica do Estado de Pernambuco (FACEPE) for project financing. 


\section{References}

AWAWDEH, M. S. Alternative feedstuffs and their effects on performance of Awassi sheep: a review. Tropical Animal Health and Production, Midlothian, v. 43, n. 7, p. 1297-1309, 2011.

AZEVÊDO, J. A. G.; VALADARES FILHO, S. C.; PINA, D. S.; DETMANN, E.; VALADARES, R. F. D.; PEREIRA, L. G. R.; SOUZA, N. K. P.; SILVA, L. F. C. Consumo, digestibilidade total, produção de proteína microbiana e balanço de nitrogênio em dietas com subprodutos de frutas para ruminantes. Revista Brasileira de Zootecnia, Viçosa, MG, v. 40, n. 5, p. 10521060, 2011.

BAUTISTA, A. R. P. L.; MIRANDA, M. S.; BATISTA, M. S.; MOREIRA, E. L. T.; SILVA, I. M.; GOMES, I. C. S. Avaliação da toxicidade oral subcrônica da bixina para ratos. Revista Brasileira de Ciências Farmacêuticas, Salvador, v. 40, n. 2, p. 229-233, 2004.

BRASIL. Ministério da Agricultura. Instrução Normativa $n^{\circ} 3$, de 7 de janeiro de 2000. Regulamento técnico de métodos de insensibilização para o abate humanitário de animais de açougue. S.D.A./M.A.A. Diário Oficial [da] União, Brasília, 24 jan. 2000, Seção 1, p. 14-16.

BRAZ, N. M.; FUENTES, M. F. F.; FREITAS, E. R.; SUCUPIRA, F. F.; MOREIRA, R. F.; LIMA, R. C. Semente residual do urucum na alimentação de poedeiras comerciais: desempenho e características dos ovos. Acta Scientiarum. Animal Sciences, Maringá, v. 29, n. 2, p. 129-133, 2007.

CEZAR, M. F.; SOUSA, W. H. Carcaças ovinas e caprinas: obtenção, avaliação e classificação. Uberaba: Editora Agropecuária Tropical, 2007. 147 p.

CLEMENTINO, R. H. Utilização de subprodutos agroindustriais em dietas de ovinos de corte: consumo, digestibilidade, desempenho e características de carcaça. 2008. Tese (Doutorado em Zootecnia) - Universidade Federal do Ceará, Fortaleza.

COSTA, R. G.; LIMA, C. A. C.; MEDEIROS, A. N.; LIMA, G. F. C.; MARQUES, C. A. T.; SANTOS, N. M. Características de carcaça de cordeiros Morada Nova alimentados com diferentes níveis do fruto-refugo de melão em substituição ao milho moído na dieta. Revista Brasileira de Zootecnia, Viçosa, MG, v. 40, n. 4, p. 866871, 2011.

DE ROSSO, V. V.; MERCADANTE, A. Z. Dyes in South America. In: BECHTOLD, T.; MUSSAK, R. (Ed.). Handbook of natural colorants. Chichester: John Wiley and Sons, 2009. p. 53-62.
FONTENELE, R. M.; PEREIRA, E. S.; PIMENTEL, P. G.; MIZUBUTI, I. Y.; MONTE, A. L. S.; CÂNDIDO, M. J. D.; REGADAS FILHO, J. G. L.; ROCHA JÚNIOR, J. N. Níveis de energia metabolizável em rações de ovinos Santa Inês: peso dos órgãos internos e do trato digestório. Semina: Ciências Agrárias, Londrina, v. 31, n. 4, p. 1095-1104, 2010.

GARCIA, C. E. R.; BOLOGNESI, V. J.; DIAS, J. F. G., MIGUEL, O. B.; COSTA, C. K. Carotenoides bixina e norbixina extraídos do urucum (Bixa orellana L.) como antioxidantes em produtos cárneos. Ciência Rural, Santa Maria, v. 42, n. 8, p. 1510-1517, 2012.

GARCIA, I. F. F.; ALVARENGA, T. I. R. C.; PEREZ, J. R. O.; ALMEIDA, A. K.; GALLO, S. B.; PEREIRA, I. G.; ALVES, N. G.; ALVARENGA, F. A. P. Allometric growth of non-carcass components in crossed lambs. Ciência Rural, Santa Maria, v. 44, n. 7, p. 1229-1235, 2014.

GERRARD, D. E.; GRANT, A. L. Principles of animal growth and development. Dubuque: Kendall/Hunt Publishing Company, 2006. 264 p.

GONZAGA NETO, S.; SILVA SOBRINHO, A. G.; ZEOLA, N. M. B. L.; MARQUES, C. A. T.; SILVA, A. M. A.; PEREIRA FILHO, J. M.; FERREIRA, A. C. D. Características quantitativas da carcaça de cordeiros deslanados Morada Nova em função da relação volumoso:concentrado na dieta. Revista Brasileira de Zootecnia, Viçosa, MG, v. 35, n. 4, p. 1487-1495, 2006.

JUNKUSZEW, A.; RINGDORFER, F. Computer tomography and ultrasound measurement as methods for the prediction of the body composition of lambs. Small Ruminant Research, Bloemfontein, v. 56, n. 1-3, p. 121125, 2005.

LOMBARDI, L.; JOBIM, C. C.; BUMBIERIS JÚNIOR, V. H.; CALIXTO JÚNIOR, M.; MACEDO, F. A. F. Características da carcaça de cordeiros terminados em confinamento recebendo silagem de grãos de milho puro ou com adição de girassol ou ureia. Acta Scientiarum. Animal Sciences, Maringá, v. 32, n. 3, p. 263-269, 2010.

MEDEIROS, G. R.; CARVALHO, F. F. R.; BATISTA, A. M. V.; DUTRA JÚNIOR, W. M.; SANTOS, G. R. A.; ANDRADE, D. K. B. Efeito dos níveis de concentrado sobre as características de carcaça de ovinos Morada Nova. Revista Brasileira de Zootecnia, Viçosa, MG, v. 38 , n. 4, p. 718-727, 2009.

MEDEIROS, G. R.; CARVALHO, F. F. R.; FERREIRA, M. A.; ALVES, K. S.; MATTOS, C. W.; SARAIVA, T. A.; NASCIMENTO, J. F. Efeito dos níveis de concentrado sobre os componentes não-carcaça de ovinos Morada Nova em confinamento. Revista Brasileira de Zootecnia, Viçosa, MG, v. 37, n. 4, p. 1063-1071, 2008. 
MEDEIROS, G. R.; COSTA, R. G.; ANDRADE, M. G. L. P.; AZEVEDO, P. S.; MEDEIROS, A. N.; PINTO, T. F.; SOARES, J. N.; SUASSUNA, J. M. A. Estado de engorduramento da carcaça de ovinos Santa Inês e Morada Nova abatidos com diferentes pesos. Actas Iberoamericanas de Conservación Animal, Córdoba, v. 5, n. 1, p. 243-246, 2011.

MIRKENA, T.; DUGUMA, G.; HAILE, A.; TIBBO, M.; OKEYO, A. M.; WURZINGER, M.; SÖLKNER, J. Genetics of adaptation in domestic farm animals: a review. Livestock Science, Foulum, v. 132, n. 1-3, p. 1-12, 2010.

MORENO, G. M. B.; SILVA SOBRINHO, A. G.; LEÃO, A. G.; OLIVEIRA, R. V.; YOKOO, M. J. I.; SOUZA JÚNIOR, S. C.; PEREZ, H. L. Características morfológicas in vivo e da carcaça de cordeiros terminados em confinamento e suas correlações. Revista Brasileira de Saúde e Produção Animal, Salvador, v. 11, n. 3, p. 888-902, 2010.

NATIONAL RESEARCH COUNCIL - NRC. Nutrient requirements of small ruminants: sheep, goats, cervids, and new world camelids. Washington: National Academy of Science, 2007. 347 p.

OLIVEIRA, N. M.; OSÓRIO, J. C. S.; SELAIVEVILLARROEL, A.; BENITEZ-OJEDA, D.; BORBA M. F. S. Produção de carne em ovinos de cinco genótipos. 5. Estimativas de qualidade e peso de carcaça através do peso vivo. Ciência Rural, Santa Maria, v. 28, n. 4, p. 665669, 1998.

PAULA, H.; PEDROSA, M. L.; ROSSONI JÚNIOR, J. V.; HARAGUCHI, F. K.; SANTOS, R. C.; SILVA, M. E. Effect of an aqueous extract of annatto (Bixa orellana) seeds on lipid profile and biochemical markers of renal and hepatic function in hipercholesterolemic rats. Archives of Biology and Technology, Curitiba, v. 52, n. 6, p. 1373-1378, 2009.

PEREIRA, E. S.; PIMENTEL, P. G.; FONTENELE, R. M.; MEDEIROS, A. N.; REGADAS FILHO, J. G. L.; VILLARROEL, A. B. S. Características e rendimentos de carcaça e de cortes em ovinos Santa Inês, alimentados com diferentes concentrações de energia metabolizável. Acta Scientiarum. Animal Sciences, Maringá, v. 32, n. 4, p. 431-437, 2010.
PEREIRA, E. S.; REGADAS FILHO, J. G. L.; ARRUDA, A. M. V.; MIZUBUTI, I. Y.; VILLARROEL, A. B. S.; PIMENTEL, P. G.; CÂNDIDO, M. J. D. Equações do NRC (2001) para predição do valor energético de coprodutos da agroindústria no nordeste brasileiro. Revista Brasileira de Saúde e Produção Animal, Salvador, v. 9, n. 2, p. 258-269, 2008.

PRESTON, H. D.; RICKARD, M. D. Extraction and chemistry of annatto. Food Chemistry, Reading, v. 5, n. 1, p. 47-56, 1980.

SILVA, D. J.; QUEIROZ, A. C. Análise de alimentos: métodos químicos e biológicos. Viçosa, MG: Editora UFV, 2002. $235 \mathrm{p}$.

SILVA, J. H. V.; SILVA, E. L.; JORDÃO FILHO, J.; RIBEIRO, M. L. G. Efeitos da inclusão do resíduo da semente de urucum (Bixa Orellana L.) na dieta para frangos de corte: desempenho e características de carcaça. Revista Brasileira de Zootecnia, Viçosa, MG, v. 34, n. 5, p. 1606-1613, 2005.

SILVA SOBRINHO, A. G. Criação de ovinos. Jaboticabal: FUNEP, 2001. 302 p.

SNIFFEN, C. J.; O'CONNOR, J. D.; VAN SOEST, P. J.; FOX, D. G.; RUSSELL, J. B. A net carbohydrate and protein system for evaluating cattle diets: II. Carbohydrate and protein availability. Journal of Animal Science, Illinois, v. 70, n. 11, p. 3562-3577, 1992.

VAN SOEST, P. J.; ROBERTSON, J. B.; LEWIS, B. A. Methods for dietary fiber, neutral detergent fiber, and nonstarch polysaccharides in relation to animal nutrition. Journal of Dairy Science, Illinois, v. 74, n. 10, p. 35833597, 1991.

WEISS, W. P. Energy prediction equations for ruminant feeds. In: CORNELL NUTRITION CONFERENCE FEED MANUFACTURES, 61., 1999, Ithaca. Proceedings... Ithaca: Cornell University, 1999. p. 176185. 
